九州大学学術情報リポジトリ

Kyushu University Institutional Repository

\title{
Heavy Metal Status of Agricultural Soils in Tuliem and Thanhtri Districts of Hanoi City, Vietnam
}

Tra, Ho Thi Lam

Laboratory of Soils, Faculty of Agricullure, Kyushu University

Egashira, Kazuhiko

Laboratory of Soils, Faculty of Agricullure, Kyushu University

https://doi.org/10.5109/24296

出版情報：九州大学大学院農学研究院紀要. 43 (3/4)，pp.489-497，1999-02. Kyushu University バージョン：

権利関係 : 


\title{
Heavy Metal Status of Agricultural Soils in Tuliem and Thanhtri Districts of Hanoi City, Vietnam
}

\author{
Ho Thi Lam Tra and Kazuhiko Egashira \\ Laboratory of Soils, Faculty of Agriculture, Kyushu University, Fakuoka 812-8581, Japan \\ (Received September 28,1998 and accepted November 6, 1998)
}

\begin{abstract}
Based on the comparison with several reference values including the Vietnam standard for heavy metal contents in soils and the correlation with selected soil properties, total heavy metals were regarded to be in a normal range for soils, except for Cn in one soil which was collected from the vegetable field and supposed to be suffercd from heavy application of pesticide. Pollution of agricultural soiks by heavy metals is still to be limited and very low in Tuliem and Thanhtri districts of Hanoi cily. In contrast, one river-sediment sample collected from the Kinuguu River flowing chrough the area contained various heavy metals by 3.5 to 12 times higher than the averages of agricultural soils, except for $\mathrm{Mn}$, suggesting severe accimulation of different heavy metals in the river bed probably due to industrial discharge.
\end{abstract}

\section{INTRODUCTION}

Hanoi is the capital of Vietnam and located in the deltaic plain of the Red River in Northern Vietnam. Climatc of the Red River delta is dominated by subtropical monsoon with mean annual rainfall of $1,600-1,900 \mathrm{~mm}$. The total area of Hanoi city is about 1,000 $\mathrm{km}^{2}$ and comprises 7 prefectures (Haibatrung, Badinh, Hoankiem, Dongda, Tayho, Caugiay, and Thanhxuan) in the center and 5 districts (Tuliem, Thanhtri, Donganh, Gialam, and Socson) around (Fig. 1). Population of Hanoi city is 2.25 million (Hanoi Statistical Office, 1996) and is increasing at the annual rate of more than $2 \%$. Since renovation (doi moi) in 1986, Hanoi has experienced rapid economical development and explosions without city planning, which have produced a lot of environmental problems for human life and agricultural production.

Tuliem and Thanhtri districts are situated in the western to southern part of Hanoi city (Fig. 1). The total area of the districts is 20,282 ha. About $40 \%$ is the agricultural land which has been one of the most productive area. Main agricultural products are rice and vegetables. They are supplied to the markets of Hanoi city throughout the year. After doi moi, intensification and diversification of cropping system were advanced, leading to the great increase of farmers' income. However, urbanization and industrialization were pushed in the districts. Twenty-two manufacturing industries are now in operation which consume nearly 35,000 tons of coal and 2,000tons of petrol per year (Ho et al., 1998a). In addition, rapid population growth was brought about. Now Tuliem and Thanhtri districts have the population of nearly one million and are the densely-populated area in Hanoi city. Rapid urbanization and industrialization, along with motorization, have seriously impacted agricultural production: diversified use and loss of agricultural lands, pollution of water and soils, and decline in the soil fertility. Among these problems, water and soil pollution is the most urgent thing to be controlled, and monitoring of agricultural water and soils started in 1995 in Hanoi city sponsored by 
Hanoi Scientific and Environrnental Office (Ho el al., 1998a). Possible sources of water and soil pollution are industrial discharge, municipal wastes, vehicle emissions, and agricultural chemicals.

In the present study, the focus was placed on the heavy metal pollution of agricultural soils of Tuliem and Thanhtri districts of Hanoi city. Samples were collected in ten locations of the districts and their heavy metal pollution was evaluated by comparing the total heavy metal contents with reference values for soils and by examining the correlation between total heavy metal contents and selected soil properties.

\section{MATERIALS AND METHODS}

\section{Location and soil samples}

Sampling sites of soils (No. 1 to No. 9) and the river system in Tuliem and Thanhtri districts are shown in Fig. 1. One river-sediment sample was collected for comparison and the sampling site (No. 10) is also shown in Fig. 1. Brief description of these samples are given in Table 1. Nine soil samples were collected to cover the whole study area and one river-sediment sample was taken from the river bed of the Kimnguu River. Soil samples were taken from paddy and upland fields, depending on their relative distribution, and at different relative land heights in the region. All samples were taken out of the surface 15-cm layer in July, 1997. After collection, they were immediately air-dried, ground with a ceramic pestle, passed through a 1-mm sieve and preserved in

Table 1. Briế description of soil and river-sedinent sanules used in the siudy.

\begin{tabular}{|c|c|c|c|c|c|}
\hline \multirow{2}{*}{$\begin{array}{l}\text { Sample } \\
\text { No. }\end{array}$} & \multicolumn{2}{|c|}{ Location } & \multirow{2}{*}{$\begin{array}{l}\text { Land use } \\
\text { (crop) }\end{array}$} & \multirow{2}{*}{$\begin{array}{l}\text { Relative land height } \\
\text { in the region }\end{array}$} & \multirow{2}{*}{$\begin{array}{c}\text { Soil classification by } \\
\text { FAO/UNESCO }\end{array}$} \\
\hline & District, & Gormune & & & \\
\hline 1 & Tuliem & Taytuu & $\begin{array}{c}\text { Jpland } \\
\text { (vegetables) }\end{array}$ & High & $\begin{array}{c}\text { Orthi-Umbri-Futric } \\
\text { Fluvisols }\end{array}$ \\
\hline 2 & & Phudien & $\begin{array}{c}\text { Paddy } \\
\text { (rice-rice) }\end{array}$ & Low & $\begin{array}{c}\text { Endo-Orthi-Entric } \\
\text { Fluvisols }\end{array}$ \\
\hline 3 & & Xuanphuong & $\begin{array}{c}\text { Paddy } \\
\text { (rice-rice- } \\
\text { vegetables) }\end{array}$ & Middle & $\begin{array}{c}\text { Orthi-Plinthi-Eutric } \\
\text { Fluvisols }\end{array}$ \\
\hline 4 & & Yenhoa & $\begin{array}{c}\text { Paddy } \\
\text { (rice-rice) }\end{array}$ & Lowest. (marshy) & $\begin{array}{l}\text { Epi-Stagni-Eutric } \\
\text { Gleysols }\end{array}$ \\
\hline 5 & Thanhtri & Mydinh & $\begin{array}{c}\text { Paddy } \\
\text { (rice-rice) }\end{array}$ & Low & $\begin{array}{c}\text { Endo-Orthi-Eutrie: } \\
\text { Fluvisols }\end{array}$ \\
\hline 6 & & Thanhliet & $\begin{array}{c}\text { Paddy } \\
\text { (rice-rice) }\end{array}$ & Middle & $\begin{array}{c}\text { Orthi-Plinthi-Eutrie } \\
\text { Fluvisols }\end{array}$ \\
\hline 7 & & Tuhiep & $\begin{array}{c}\text { Paddy } \\
\text { (spinach) }\end{array}$ & Low & $\begin{array}{c}\text { Endo-Orthi-Eutric } \\
\text { Fluvisols }\end{array}$ \\
\hline 8 & & Lienninh & $\begin{array}{c}\text { Paddy } \\
\text { (rice-rice- } \\
\text { vegetables) }\end{array}$ & Middle & $\begin{array}{c}\text { Orthi-Plinthi-Eutric } \\
\text { Fluvisols }\end{array}$ \\
\hline 9 & & Daiang & $\begin{array}{c}\text { Paddy } \\
\text { (rice-rice) }\end{array}$ & Lowest (marshy) & $\begin{array}{c}\text { Epi-Stagni-Eutric } \\
\text { Gleysols }\end{array}$ \\
\hline 10 & & Tranphu & - & River bed & - \\
\hline
\end{tabular}




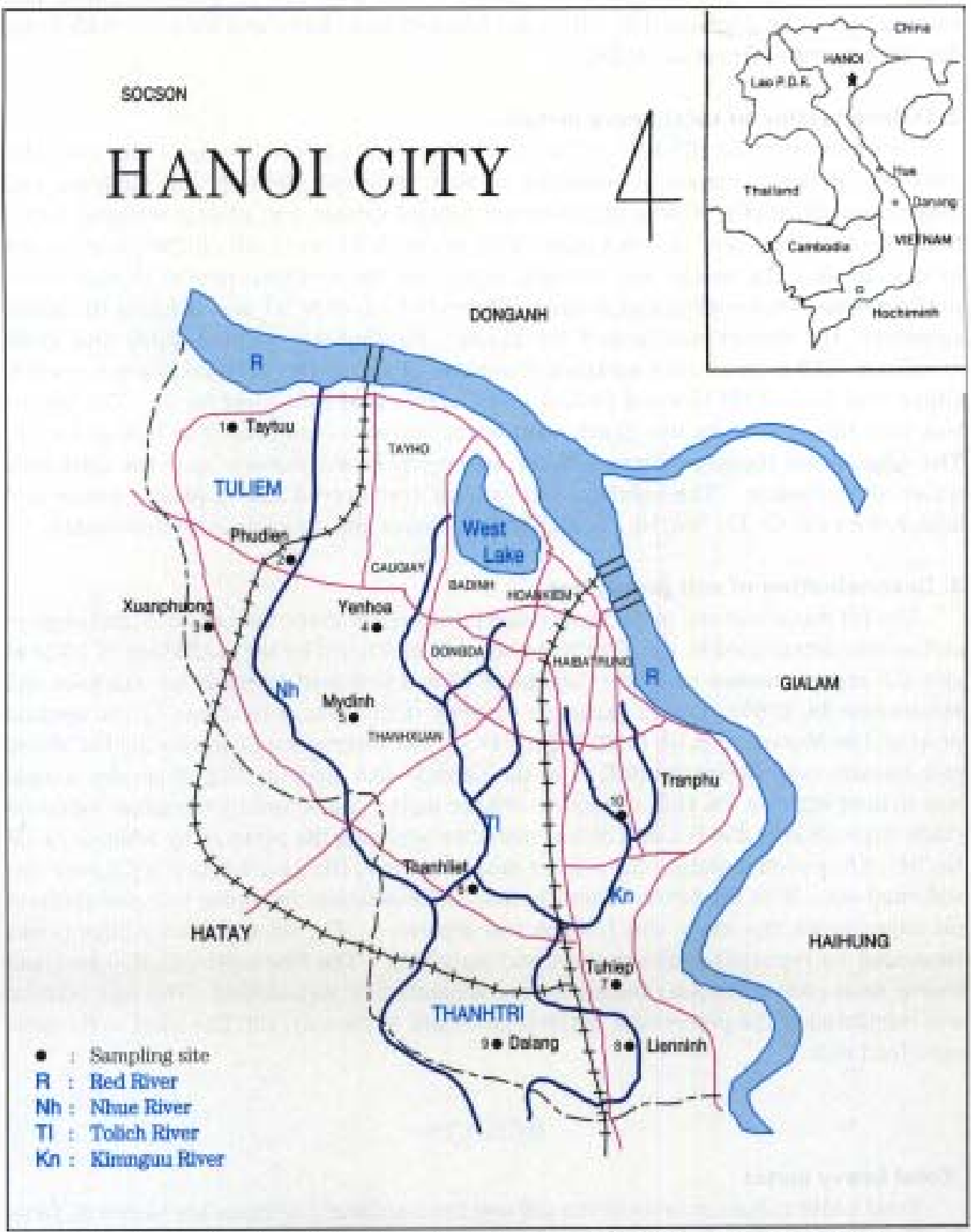

Pig. 1. Sampling sites and the river system in Tuhiem and Thanhtri ifistricts of Hanoi city. 
plastic bottles. They were brought to Japan by air and subjected to chemical and physical andilyses. Clay mineralogically, all the samples were found to be quite similar to one another and to be dominated by clay mica followed by chlorite and kaolinite with being devoid of smectite (Ho et al., 1998b).

\section{Determination of total heavy metals}

Digestion with the $\mathrm{HF}^{-}-\mathrm{HNO}_{3}-\mathrm{HClO}_{+}$acid treatment was used to determine the total contents of heavy metals (Committee of Soil Standard Methods for Analyses and Measurements, 1986). One g of pulvcrized air-dry sample was exactly wcighed into a teflon beaker and placed on a hot plate. Five $\mathrm{mL}_{4}$ of $\mathrm{HClO}_{4}$ and $5 \mathrm{~mL}$ of $\mathrm{HNO}_{3}$ were added to the sample. The beaker was covered, heated for $3 \mathrm{~h}$, and then heated without cover until dryness. After cooling and gradual addition of $5 \mathrm{~mL}$ of $\mathrm{HClO}_{4}$ and $10 \mathrm{~mL}$ of $\mathrm{HF}$ in this sequence, the beaker was heated for $15 \mathrm{~min}$. Heating was once stopped and again continued until dryness after addition of another $10 \mathrm{~mL}$ of HF. The beaker was cooled, added with $5 \mathrm{~mL}$ of $6 \mathrm{M} \mathrm{HCl}$ and $1 \mathrm{~mL}$ of $\mathrm{HNO}_{3}$, and heated with cover for $1 \mathrm{~h}$. The beaker was then filled-up to its two-thirds with water, covered, and heated to boiling for $2 \mathrm{~h}$. The solution was transferred into a $50-\mathrm{mL}$ volumetric flask and made up to the mark with water after cooling. The solution was quickly transferred into a plastic bottle and analyzed for $\mathrm{Cd}, \mathrm{Cr}, \mathrm{Cu}, \mathrm{Mn}, \mathrm{Ni}, \mathrm{Pb}$, and $\mathrm{Zn}$ by a atomic absorption spectrophotometer.

\section{Determination of soil properties}

The $\mathrm{pH}$ was measured in the suspension having a soil:water ratio of 1:2.5; and orgaric carbon was determined by the Tyurin method and multiplied by the coefficient of 1.724 to give the organic matter content (Committce of Soil Standard Methods for Analyses and Measurements, 1986). Cation exchange capacity (CEC) was determined by the method proposed by Muramoto et al. (1992). Free $\mathrm{Fe}_{2} \mathrm{O}_{3}$ was detcrmined by the method of Mehra and Jackson (van Reeuwijk, 1992). In the particle-size analysis, $10 \mathrm{~g}$ of air-dry sample was treated with hot $7 \% \mathrm{H}_{2}$ to remove organic matter, dispersed by ultrasonic vibration (tank-type; $38 \mathrm{kHz}, 250 \mathrm{~W}$ ), and deflocculated by adjusting the $\mathrm{pH}$ to 10 by addition of $1 \mathrm{M}$ $\mathrm{NaOH}$. After sedimentation for a fixed period of time, the clay fraction $(<2 \mu \mathrm{m})$ was siphoned out. With repetition of sonification-sedimentation-siphoning with intermittent $\mathrm{pH}$ adjustments, the whole clay fraction was separated. The silt fraction $(2-20 \mu \mathrm{m})$ was separated by repeated sedimentation and siphoning. The fine sand $(20-200 \mu \mathrm{m})$ and coarse sand $(200-1,000 \mu \mathrm{m})$ fractions werc separated by wet-sieving. The clay content was calculated as the percentage to the total weight of the clay, silt, fine sand, and coarse sand fractions.

\section{RESULTS}

\section{Total heavy metal}

Total heavy metal contents of the soil and river-sediment samples are shown in Table 2. The contents of the nine soil samples ranged between 0.16 and $0.36 \mathrm{mg} \mathrm{kg}^{-1}$ for $\mathrm{Cd}$; 62.5 and $112.8 \mathrm{mg} \mathrm{kg}^{-1}$ for $\mathrm{Cr}, 40.1$ and $73.2 \mathrm{mg} \mathrm{kg}^{\prime}$ for $\mathrm{Cu}, 378$ and $750 \mathrm{mg} \mathrm{kg}{ }^{1}$ for $\mathrm{Mn}$, 33.6 and $66.0 \mathrm{mg} \mathrm{kg}^{-1}$ for $\mathrm{Ni}, 31.9$ and $45.3 \mathrm{mg} \mathrm{kg}{ }^{\prime}$ for $\mathrm{Pb}$, and 98.2 and $137.2 \mathrm{mg} \mathrm{kg}^{-1}$ for $\mathrm{Zn}$. The highest content of the heavy metals was observed for sample No. 6 which had 
the highest clay content among the soil samples (Table 6), except for $\mathrm{Cd}$ and $\mathrm{Cu}$. The highest content of Cd was obtained for sample No. 7 taken from paddy field cultivated for spinach. In case of $\mathrm{Cu}$, the highest content was obtained in sample No. 1 taken from the upland (vegetables) field, while the contents of the other eight samples were in a narrow range of $40-50 \mathrm{mg} \mathrm{kg}^{-1}$.

Table 3 shows correlation coeflicients between heavy metals in their total contents for the ninle soils. Among the seven heavy metals, $\mathrm{Cr}$ and $\mathrm{Ni}$ exhibited the highest correlation coefficient. Zinc showed the significant correlation at $1 \%$ level with both $\mathrm{Cr}$

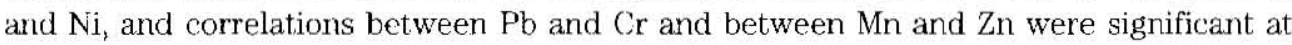
$5 \%$ level. The significant correlations among $\mathrm{Cr}, \mathrm{Ni}$, and $\mathrm{Zn}$ were reported by Domingo and Kyuma (1983b) for tropical Asian paddy soils. Cadmium and $\mathrm{Cu}$ did not show a significant correlation with any other heavy metals.

Total heavy metal contents of the river-sediment from the Kimuguu River were quite high contuared to those of the agricultural soils, except for Mn which was in the same range as for the soils (Table 2). Contents of total $\mathrm{Cd}, \mathrm{Cr}, \mathrm{Cu}, \mathrm{Ni}, \mathrm{Pb}$, and $\mathrm{Zn}$ were 11.8 , $4.9,5.5,3.5,4.0$, and 9.5 times higher, respectively, than the average values of the respective heavy metals for the soils.

Table 2. Contents or total heavy metals in the soil and river-sediment. samples ( $\left.\mathrm{mg} \mathrm{kg}{ }^{~}\right)$.

\begin{tabular}{ccccccrr}
\hline $\begin{array}{c}\text { Sample } \\
\text { No. }\end{array}$ & $\mathrm{Cd}$ & $\mathrm{Cr}$ & $\mathrm{Cu}$ & $\mathrm{Mn}$ & $\mathrm{Ni}$ & $\mathrm{Pb}$ & $\mathrm{Zn}$ \\
\hline 1 & 0.16 & 62.5 & 73.2 & 741 & 33.6 & 31.9 & 114.5 \\
2 & 0.22 & 72.3 & 41.3 & 504 & 35.3 & 43.6 & 106.2 \\
3 & 0.16 & 78.9 & 44.3 & 378 & 41.5 & 43.2 & 105.8 \\
4 & 0.23 & 82.0 & 50.0 & 545 & 45.6 & 45.1 & 116.9 \\
5 & 0.16 & 65.8 & 40.1 & 482 & 36.6 & 36.8 & 98.2 \\
6 & 0.19 & 112.8 & 43.0 & 750 & 66.0 & 45.3 & 137.2 \\
7 & 0.36 & 75.9 & 43.3 & 383 & 40.9 & 38.6 & 100.2 \\
8 & 0.19 & 68.9 & 40.1 & 556 & 37.2 & 36.1 & 105.5 \\
9 & 0.26 & 68.9 & 42.2 & 451 & 37.7 & 36.4 & 102.6 \\
10 & 2.48 & 376 & 258 & 719 & 145.5 & 157.5 & 1040 \\
\hline & & & & & & (Oven-dry basis)
\end{tabular}

Table 3. Correlation coefficients between contents of total heavy metals.

\begin{tabular}{ccccccc}
\hline & $\mathrm{Cr}$ & $\mathrm{Ni}$ & $\mathrm{Zn}$ & $\mathrm{Pb}$ & $\mathrm{Mn}$ & $\mathrm{Cd}$ \\
\hline $\mathrm{Ni}$ & $0.985^{* *}$ & & & & & \\
$\mathrm{Zn}$ & $0.828^{* *}$ & $0.841^{* *}$ & & & & \\
$\mathrm{~Pb}$ & $0.731^{*}$ & 0.638 & 0.462 & & & \\
$\mathrm{Mn}$ & 0.359 & 0.415 & $0.787^{*}$ & -0.095 & & \\
$\mathrm{Cd}$ & 0.000 & -0.253 & -0.477 & 0.000 & 0.055 & \\
$\mathrm{Cu}$ & -0.251 & -0.212 & 0.242 & -0.440 & 0.557 & -0.259 \\
\hline
\end{tabular}

\footnotetext{
**and * indicate significance at $1 \%$ and $5 \%$ levels, respectively.
} 


\section{Comparison with reference values}

Table 4 gives the Vietnam standard for heavy metal contents in soils (Ministry of Science and Environment, 1995) which was recentiy established to control environmental pollution. Comparison of total $\mathrm{Cu}, \mathrm{Pb}$, and $\mathrm{Zn}$ contents of agricultural soils (Table 2) with the standard value for the respective heavy metals uncler the spccified pH (Table 6) indicated that none of the soils excceded the standard values. In contrast to the soils, contents in the river-sediment were extraordinarily over the standard values for $\mathrm{Zn}$ and $\mathrm{Pb}$ and nearly equal to the standard value for $\mathrm{Cu}$.

Table 5 lists the reported values of total heavy metals in the lithosphere and in soils, quoted from Lindsay (1979), Sposito (1989), and Domingo and Kyuma (1983a). By comparing the data of the present study with the values of Table 5 , it was indicated that total heavy metal contents of agricultural soils were all in the common ranges of $\mathrm{Cd}$, Cr, $\mathrm{Cu}, \mathrm{Mn}, \mathrm{Ni}, \mathrm{Pb}$, and $\mathrm{Zn}$ for soils. Among these seven heavy metals, contents of $\mathrm{Cd}, \mathrm{Cr}, \mathrm{Mn}$, and $\mathrm{Ni}$ were in the similar magnitude to the selected averages for soils, but contents of other three heavy metals were higher than them. It may indicate the relatively high background levels of $\mathrm{Cu}, \mathrm{Pb}$, and $\mathrm{Zn}$ in the studjed area and probably in the Red River delta area. If compared with the averages for Victnam (Mekong delta) paddy soils and tropical Asian paddy soils, the contents in the present soils were considerably higher for

Table 4. Standard for heavy metal contents of soils in Vietram (mg kg ').

\begin{tabular}{rrrr|rrrrr}
\hline $\mathrm{pH}$ & $\mathrm{Cu}$ & $\mathrm{Pb}$ & $\mathrm{Zn}$ & $\mathrm{pH}$ & $\mathrm{Cu}$ & $\mathrm{Pb}$ & $\mathrm{Zn}$ \\
\hline 3.5 & $<15$ & $<20$ & $<20$ & 6.0 & $<120$ & $<70$ & $<200$ \\
4.0 & $<20$ & $<25$ & $<30$ & 6.2 & $<180$ & $<75$ & $<300$ \\
4.5 & $<25$ & $<30$ & $<40$ & 6.5 & $<250$ & $<80$ & $<320$ \\
5.0 & $<40$ & $<40$ & $<60$ & 7.0 & 260 & 80 & 340 \\
5.5 & $<60$ & $<50$ & $<90$ & 7.5 & 270 & 80 & 360 \\
5.7 & $<80$ & $<60$ & $<110$ & 8.0 & 280 & 80 & 370 \\
\hline
\end{tabular}

Table 5. Contents of various heavy metals in the lithosphere and soils.

\begin{tabular}{|c|c|c|c|c|c|c|}
\hline \multirow{2}{*}{$\begin{array}{l}\text { Element } \\
\\
\mathrm{Cd}\end{array}$} & \multirow{2}{*}{$\begin{array}{l}\text { Content in } \\
\text { lithosphere } \\
\text { (mg kg :) } \\
0.2\end{array}$} & \multirow{2}{*}{$\begin{array}{l}\text { Comimon } \\
\text { range for } \\
\text { soils } \\
\left(\mathrm{mg} k \mathrm{~kg}^{\prime}\right) \\
\\
0.01-0.70\end{array}$} & \multicolumn{4}{|c|}{$\begin{array}{l}\text { Selected average for soils } \\
\text { (mg kg) }\end{array}$} \\
\hline & & & 0.06 & 0.85 & - & - \\
\hline $\mathrm{Cr}$ & 200 & $1-1000$ & 100 & 54 & 137 & 136 \\
\hline $\mathrm{Cu}$ & 70 & $2-100$ & 30 & 25 & 23 & 33 \\
\hline $\mathrm{Mn}$ & 900 & $20-3000$ & 600 & 550 & - & - \\
\hline $\mathrm{Ni}$ & 100 & $5-500$ & 40 & 19 & 20 & 22 \\
\hline $\mathrm{Pb}$ & 16 & $2-200$ & 10 & 19 & - & - \\
\hline $7_{n 1}$ & 80 & $10-300$ & 50 & 60 & 82 & 66 \\
\hline Reference & 1 & 2 & 3 & 4 & 5 & 6 \\
\hline
\end{tabular}

1, 2, and 3: Lindsay (1979); 4: Sposite (1989); 5: Domingo and Kyuma (1983a) for Vietnam (Mekong (telta) paddy soils; and 6: Domingo and Kyuma (1983a) for tropical Asian paddy soils. 
$\mathrm{Cu}, \mathrm{Ni}$, and $\mathrm{Zn}$ but lower for $\mathrm{Cr}$.

As for the river-sediment, contents of total $\mathrm{Cd}, \mathrm{Cu}$, and $\mathrm{Zn}$ were remarkably higher than the selected averages for soils and even exceeded the common range for soils. Contents of total $\mathrm{Cr}, \mathrm{Ni}$, and $\mathrm{Pb}$ were within the common range for soils but considerably over the selected averages for soils. Only total $\mathrm{Mn}$ was in the similar magnitude to the selected averages for soils.

\section{Correlation with soil properties}

Selected properties of the soil and river-sediment samples are given in Table 6, and correlation coefficients between the soil properties and total heavy metal contents calculated for the nine soil samples are shown in Table 7. Among the seven heavy metals, $\mathrm{Cr}$ and $\mathrm{Ni}$ showed the highly significant and positive correlation with free $\mathrm{Fe}_{2} \mathrm{O}_{3}$ oxide and clay contents. The correlation between total $\mathrm{Zn}$ and free $\mathrm{Fe}_{2} \mathrm{O}_{3}$ was also significant at $1 \%$ level. Thus variation of total $\mathrm{Cr}, \mathrm{Ni}$, and $\mathrm{Zn}$ contents of agricultural soils of the studied area can be well explained by the contents of free $\mathrm{Fe}_{2} \mathrm{O}_{3}$ and/or clay, suggesting that

Table 6. Selected properties of the soil and river-sediment samples.

\begin{tabular}{cccccc}
\hline $\begin{array}{c}\text { Sample } \\
\text { No. }\end{array}$ & $\begin{array}{c}\mathrm{pH} \\
\left(\mathrm{H}_{2} \mathrm{O}\right)\end{array}$ & $\begin{array}{c}\text { Organic } \\
\text { matter } \\
\left(\mathrm{g} \mathrm{kg}^{2}\right.\end{array}$ & $\begin{array}{c}\text { Clay } \\
(<2 \mu \mathrm{m}) \\
(\%)\end{array}$ & $\begin{array}{c}\text { Free } \\
\mathrm{Fe}_{3} \mathrm{O}_{3} \\
\left(\mathrm{~g} \mathrm{~kg}^{-}\right)\end{array}$ & $\begin{array}{c}\text { CEC } \\
\left(\mathrm{cmol}^{2}+\mathrm{kg}^{-1}\right)\end{array}$ \\
\hline 1 & 7.21 & 15.9 & 17.8 & 22.8 & 18.0 \\
2 & 7.26 & 28.3 & 21.2 & 22.7 & 24.3 \\
3 & 5.93 & 30.3 & 46.4 & 33.6 & 20.9 \\
4 & 6.27 & 21.9 & 41.1 & 32.8 & 24.4 \\
5 & 5.72 & 24.7 & 29.1 & 25.8 & 23.7 \\
6 & 6.75 & 30.9 & 63.4 & 48.6 & 22.1 \\
7 & 5.93 & 26.0 & 34.9 & 26.1 & 20.6 \\
8 & 6.47 & 18.8 & 29.5 & 27.7 & 24.5 \\
9 & 5.91 & 22.2 & 32.2 & 25.6 & 30.7 \\
10 & 6.85 & 105.0 & 30.8 & 43.8 & \\
\hline
\end{tabular}

Table 7. Correlation coefficients between total heavy metal contents and selected soil properties.

\begin{tabular}{cccccc}
\hline & $\begin{array}{c}\mathrm{pH} \\
\left(\mathrm{H}_{2} \mathrm{O}\right)\end{array}$ & $\begin{array}{c}\text { Organic } \\
\text { matter }\end{array}$ & $\begin{array}{c}\text { Clay } \\
(<2 \mu \mathrm{m})\end{array}$ & $\begin{array}{c}\text { Free } \\
\mathrm{Fe}_{2} \mathrm{O}_{3}\end{array}$ & CEC \\
\hline $\mathrm{Cr}$ & 0.095 & 0.640 & $0.914^{* *}$ & $0.954^{* *}$ & $0.666^{*}$ \\
$\mathrm{Ni}$ & 0.032 & 0.549 & $0.922^{* *}$ & $0.968^{* *}$ & 0.655 \\
$\mathrm{Zn}$ & 0.484 & 0.207 & 0.646 & $0.816^{* *}$ & 0.375 \\
$\mathrm{~Pb}$ & 0.032 & $0.766^{*}$ & $0.678^{*}$ & 0.642 & $0.668^{*}$ \\
$\mathrm{Mn}$ & $0.695^{*}$ & -0.297 & 0.144 & 0.377 & 0.000 \\
$\mathrm{Cd}$ & -0.266 & 0.084 & 0.000 & -0.176 & 0.247 \\
$\mathrm{Cu}$ & 0.494 & -0.592 & -0.349 & -0.215 & -0.614 \\
\hline
\end{tabular}

**and * indicate significance at $1 \%$ and $5 \%$ levels, respectively. 
artificial contamination or pollution by $\mathrm{Cr}, \mathrm{Ni}$, and $\mathrm{Zn}$ is negligible or very low. Lead showed the correlation coefficient at $5 \%$ level with organic matter and clay contents, and $\mathrm{CEC}$, while Mn showed the significant correlation with $\mathrm{pH}$. It again suggests that the pollution by $\mathrm{Pb}$ and $\mathrm{Mn}$ is negligible or very low like $\mathrm{Cr}, \mathrm{Ni}$, and $\mathrm{Zn}$. According to Domingo and Kyuma (1983b) $\mathrm{Cu}$ showed the highly significant correlation with organic matter status. In the present study, however, $\mathrm{Cu}$ showed no significant correlation with any of the soil properties. Cadmium also showed no significant correlation with the selected soil properties.

\section{DISCUSSION}

Hanoi city has experienced rapid economic development but now is suffered from pollution of water and soils. In order to clarify the pollution of soils in the industrialized and densely-populated area of Hanoi city, soil samples were collected from agricultural soils in Tuliem and Thanhtri districts. Heavy metals were focused on $\mathrm{Cd}, \mathrm{Cr}, \mathrm{Cu}, \mathrm{Mn}, \mathrm{Ni}$, $\mathrm{Pb}$, and $\mathrm{Zr}$. Nine soil samples which were collected to cover the whole area with different, land uses and land positions were evaluated by the comparison with reference values of total heavy metal contents for soils and the correlation with selected soil properties. However, they did not show any indication of artificial contamination or poilution by heavy metals, since total heavy metal contents were below the Vietnam standard for heavy metal contents in soils and within the common range and around the selected averages for soils. In addition, tolal heavy metal contents were significantly correlated with one or nore than two of the selected soil properties.

One possible pollution was indicated for $\mathrm{Cu}$ of the upland field where vegetables are cultivated throughout the year. Total Cu content at the field did not exceed the Vietnam standard for $\mathrm{Cu}$ in soils and was within the common range for soils, but higher by $20-30$ $\mathrm{mg} \mathrm{kg}$ ' than the total $\mathrm{Cu}$ contents of the other eight soil samples which showed the quite similar contents with one another. In the vegetable field around the sampling site, farmers conveniently apply a lot of pesticide to keep growth and production of vegetables. Total Cu content of the vegetable field is below the critical level but would be over that level in near future by continuation of heavy application of pesticide.

In contrast to the agricultural soils, the river-sediment which was collected from the Kimnguu River showed the quite high contents of heavy metals, except for Mn, with an indication of their accumulation in the river bed. The most heavy accumulation was indicated for $\mathrm{Zn}$. Total $\mathrm{Zn}$ content of the river-sediment was about $1,000 \mathrm{mg} \mathrm{kg}{ }^{1}$ which was remarkably over the Vietnam standard for $\mathrm{Zn}$ in soils and cxceeded the common range for soils. Total Cd content of the river-sediment was $2.48 \mathrm{mg} \mathrm{kg}^{-1}$ and exceeded the common range for soils. Following $\mathrm{Zn}$ and $\mathrm{Cd}$, considerable accumulation of $\mathrm{Cr}, \mathrm{Cu}, \mathrm{Ni}$, and $\mathrm{Pb}$ was noticed. Severe pollution by different heavy metals was indicated for the river-sediment, and discharge of industrial wastes from many factories along the river can be suggested as a main source of the heavy metal accumulation, but only for one site. More river-sediment samples should be collected from different rivers of the area and measured for total heavy metals to identify the magnitude and extension of heavy metal pollution in the river bed of Tuliem and Thanhtri districts as a future work.

In the Red River delta area, farmers have for a long time used mud of rivers and 
canals as a organic amendment or fertilizer to keep soil fertility. Accumulation of heavy metals in the river-sediment is probably a recent occurrence, even if it is a real matter. However, continuation of application of the river-sediment to the surface of agricultural field would become a probable source of soil pollution by heavy metals.

\section{CONCLUSIONS}

Pollution of agricultural soils by heavy metals at Tuliem and Thanhtri districts was not indicated except for $\mathrm{Cu}$ at one upland field. Total $\mathrm{Cu}$ content of that field was higher by $20-30 \mathrm{mg} \mathrm{kg}^{-1}$ than those of the other fields, although it was below the critical level of the Vietnam standard. These districts have been rapidly industrialized and populated in Hanoi, but pollution of agricultural soils by heavy metals is limited and very low up to the present.

\section{REFERENCES}

Committee of Soil Standard Methods for Aralyses and Measurements (ed.) 1986 Soil Standard Methods for Analyses and Measurements. Hakuyusha, Tokyo (in Japarlese)

Domingo, L. E. and K. Kyuma 1983 a Trace elements in tropical Asian paddy soils. I. Total trace element. status. Soil Sci. Plant Nutr., 29: 439-452

Domingo, L. E. and K. Kyuma 1983b Trace elements in tropical Asian paddy soils. 11. Correlation of total trace element status with various soil characters. Soil Sci. Plant Nutr., 29: 453-462

Hanoi Statistical Office 1996 Statistical Yearbook. Hanoi (in Viemamese)

Ho Thi Lam Tra, Ngıyen Dinh Manh, Do Nguyen Hai, and K. Egashira 1998a Pollution of water and agricultural soils in Tuliem and Thanhtri districts of Hanoi city, Vietnam-A report. J. Fuc. Agr., Kyushu Univ., 42: 509-521

Ho Thi Lam Tra, Hoang Xuan Phuong, and K. Egashira $1998 \mathrm{~b}$ Chemical, physical and mineralogical properties of soils in Tuliem and Thanhtri districts of Hanoi city, Vietnam. J. Fac. Agr, Kyushu Univ., 43: 281-291

lindsay, W. L. 1979 Chemical Equilibria in Soils. Wiley-Interscience Publication, New York, pp. 6-8

Ministry of Science and Environment 1995 The Standard for the Quality of Water and Soils. Hanoi (in Vietnamese)

Muramoto, J., I. Goto, and M. Ninaki 1992 Rapid analysis of exchangeable cations and cation exchange capacity (CEO) of soil by a shaking extraction method. Jpn. J. Soil Sci. Plant Nutr., 63:210-215 (in Japanese with English abstract)

Sposito, G. 1989 The Chemistry of Soils. Oxford Liniversity Press, New York, p. 3-7

van Reeuwijk, L. P. 1992 Procedures for Soil Analysis, 3rd ed. ISRIC, Wageningen 